\title{
CURRENT DISTRIBUTION AND CONSERVATION OF NAJAS TENUISSIMA (HYDROCHARITACEAE)
}

\author{
Elena V. Vargot ${ }^{1,2,3}$, Andrey V. Shcherbakov ${ }^{4}$, Yana V. Bolotova ${ }^{5}$, Pertti Uotila ${ }^{6}$ \\ ${ }^{1}$ Mordovia State Nature Reserve, Russia \\ ${ }^{2}$ National Research Ogarev Mordovia State University, Russia \\ ${ }^{3}$ National park «Smolny», Russia \\ e-mail:vargot@yandex.ru \\ ${ }^{4}$ Lomonosov Moscow State University, Russia \\ e-mail:shch_a_w@mail.ru \\ ${ }^{5}$ Amur Branch of Botanical Garden-Institute of FEB RAS, Russia \\ e-mail:yabolotova@mail.ru \\ ${ }^{6}$ University of Helsinki, Finland \\ e-mail:pertti.uotila@helsinki.fi
}

Received: 30.09 .2016

\begin{abstract}
Najas tenuissima (Hydrocharitaceae) is an endangered relict species with a disjunctive range in Eastern Europe, in the Urals, in Siberia and Kazakhstan, and in the Far East, in Japan. More than 60 locations of the plant were revealed during the last 160 years. More than 30 of them are located in the waterbodies of Southern Finland. The species is known reliably in Fennoscandia, Latvia, Russian Federation (Leningrad region, Novgorod region, Tver region, Ryazan region, Republic of Mordovia, Sverdlovsk region, Chelyabinsk region, Irkutsk region, Amur region, Krasnoyarsky Krai and Primorsky Krai), Northern and Eastern Kazakhstan and Japan. The paper summarises the data on locations of the species in the above mentioned regions. We suggest that species grows in floodplain waterbodies on the right bank of the Amur river in China. Reasons why the species has disappeared are given and discussed. An anthropogenic impact on aquatic ecosystems was denoted as the main factor causing the populations' reduction of Najas tenuissima in the XX-XXI centuries. We have shown a reduction in the number of populations found from 1857 to 1936 (in Leningrad region, Tver region, Novgorod region, Ryazan region of Russia), as well as the appearance of new populations of the species found from 2006 to 2016 (in Latvia and Russia: Amur region, Chelyabinsk region, Irkutsk region, Republic of Mordovia). We assumed the possibilities of resettlement of the species at new places. It was noted that species conservation is possible only if the territorial protection of Najas tenuissima locations will be organised.
\end{abstract}

Key words: Najas tenuissima, Protected Areas, range, Red Data Book, relict species, resettlement.

\section{Introduction}

At present, many native species are in need of study and conservation. Fundamental documents regulating the conservation of the species in Eurasia are The IUCN Red List of Threatened Species (IUCN, 2016), Red Lists of European and Asian countries, Red Data Book of the Russian Federation (Bardunov \& Novikov, 2008), Red Data Books of Russian regions, approved regional lists of rare and protected species. To assess the threat of a population reduction or extinction of a species, a comprehensive study of its distribution is necessary, as well as its ecology and biology, possibilities and consequences of human impact. The order of the State Committee on Ecology of the Russian Federation by 03.10.1997 №419a, «On Approval of the Procedure of maintenance of the Red Data Book of the Russian Federation» (registered in the Ministry of Justice of the Russian
Federation in 12.24.1997 №1435) describes in detail the criteria for the rarity of the species in Russia, as well as main tasks and stages of maintenance of the Red Data Book of Russian Federation are denoted. Programmes for maintenance of regional Red Data Books are drawn up on the base of the Order mentioned above, «Methodological recommendations for maintenance of Red Data Book of region of Russian Federation» approved by guidance letter of Ministry of Natural Resources of Russia № 02-12-53/5987 by 27.06 .2006 , as well as regional provisions about Red Data Books. Information about rare species is presented in sufficient details in the regional Red Data Books. At the same time some information on the distribution, biology and ecology of rare species may remain unaccounted in the Red Data Book of the Russian Federation due to a communication gap and inaccessibility of many regional materials. 
In this study, we have summarised the material about an aquatic relict plant species - Najas tenuissima (A. Braun ex Magnus) Magnus (Caulinia tenuissima (A. Br. ex Magnus) Tzvelev). This species was included in the Red Data Book of USSR (1978, 1984), RSFSR (1988); at present, it is included in the Red Data Book of the Russian Federation (Bardunov $\&$ Novikov, 2008) within the rarity category 1 (Endangered species). Principally new data on the Najas tenuissima distribution within Russia have been accumulated over a 9-year period after publishing of the Russian Red Data Book, as well as the state of earlier known populations was analysed.

The species was originally described in 1864 under the name Najas minor var. tenuissima A. Braun ex Magnus (Magnus, 1870). Kolesnikova (1965) clarified the relationship between the species of the genus Najas L. in her detailed publication; she discussed the problem of the independency of the genera Najas L. and Caulinia Willd. Later N.N. Tzvelev firmly classified the species into the genus Caulinia Willd. (based on the structure of fruits and on the monoeciousness of shoots) and determined the species as Caulinia tenuissima (A. Br. ex Magnus) Tzvelev (Tzvelev, 1976). Until the last decade, different scientists have classified the species of the genera Najas L. and Caulinia Willd. into the family Najadaceae Juss. In modern systems of higher plants APG II (2003) and APG III (2009) Najas tenuissima is classified as a representative of the family Hydrocharitaceae.

Najas tenuissima is an annual aquatic plant, with a length of 8-20 cm, with very brittle stems and thin $(0.2-0.5 \mathrm{~cm})$ leaves (Fig. 1B). The leaf sheaths have an irregularly-toothed shoulder. This species differs of other members of the genus Najas due to the sculpture of the seedcoat that consists of 25-30 rows of cells elongated in lengthwise direction (the length of the cells exceeds the width 2-7 times). The seeds are 2-3 $\mathrm{mm}$ in length, oblong-elliptic (Fig. 1A). Najas tenuissima is a monoecious plant. The small, inconspicuous flowers are formed in leaf sheaths. It blooms in June, fructifies in August (Lisitsyna et al., 2009).

Publications of many researchers - taxonomists, phytogeographers, paleobotanists, florists - were the basis of this paper. These publications are dedicated to the systematic treatment of the genus Najas L. (Tzvelev, 1976), the former and current distribution of species within the genus Najas, family Najadaceae (Kolesnikova, 1965; Veisberg, 2011) and Najas tenuissima (Samsel, 1939; Gorlova, 1960; Bolotova \& Kozyr, 2008; Suško, 2008, 2015; Issakainen et al., 2011). Our work generalises the data of the regional floristical reports (Tikhomirov, 1975, 1986; Tzvelev, 1987, 2000; Kazakova, 2004), Red Data Book of the Russian Federation (Tzvelev, 2008), regional Red Data Books and materials to their maintenance (Uotila \& Tzvelev, 1998; Tzvelev, 2000b, 2004; Bolotova, 2009; Shcherbakov \& Kazakova, 2011; Stepanov, 2012; Silaeva et al., 2014; Resolution, 2015; Khapugin et al., 2016), floristical records (Volobaev, 1991; Chepinoga et al., 2013), European databases (e.g., Uotula, 2009). We have also used the herbarium collections of the Botanical Institute of RAS (LE), Moscow State University (MW), Institute for biology of inland waters of RAS (IBIW), Mordovia State Nature Reserve (HMNR), Mordovia State University (GMU), and the Institute of Plant and Animal Ecology, Ural Branch of RAS (SVER).

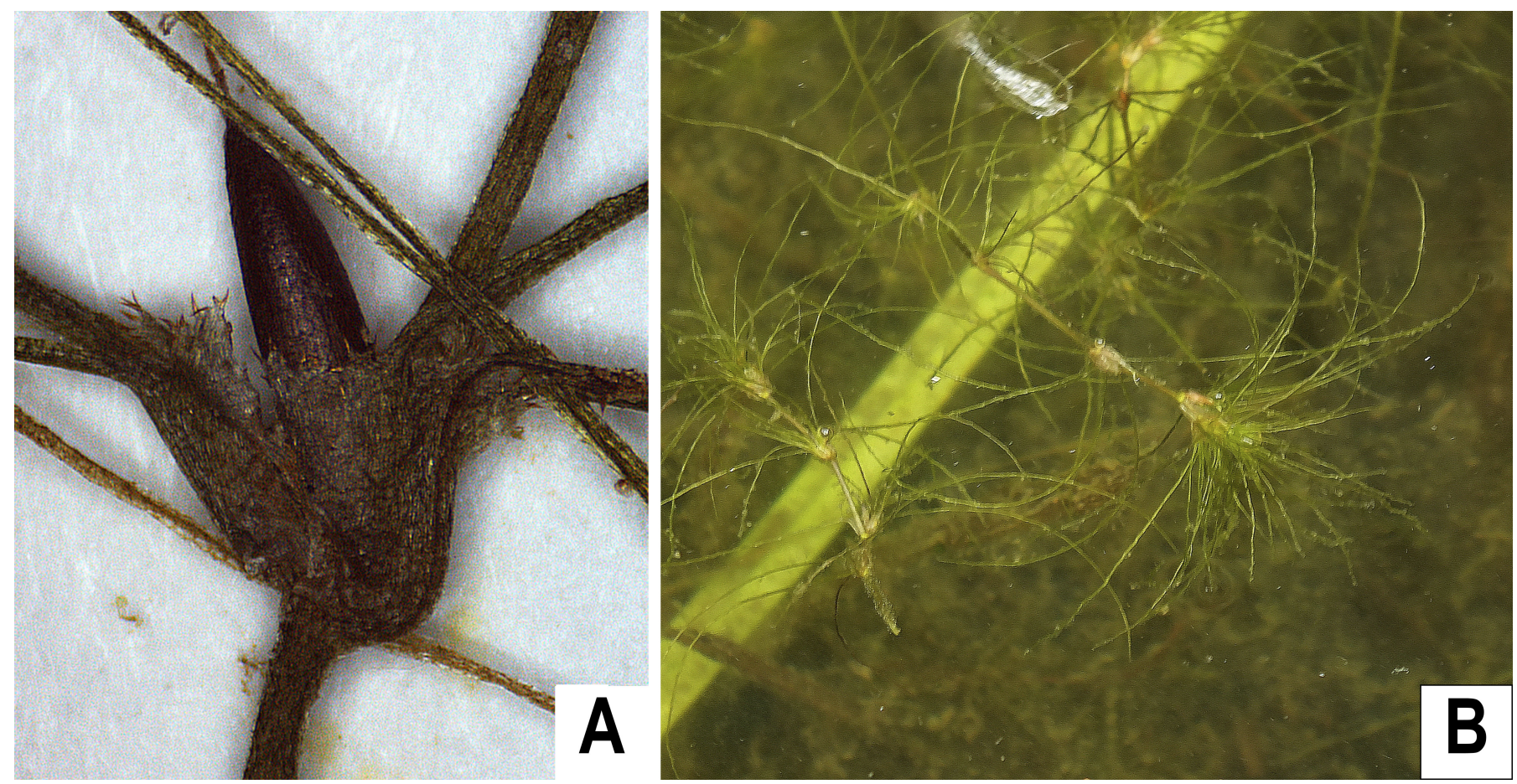

Fig. 1. Najas tenuissima: A - fruit in leaf sheath; B - plant in the water. 
About distribution and ecology of Najas tenuissima

Najas tenuissima is a relict species of the subboreal period. According to paleobotanical data, this species was found in ancient sediments at the beginning of the lower - middle Pliocene (Kolesnikova, 1965). Gorlova (1960) summarised the material about the former distribution of Najas tenuissima. She pointed out that this species had a considerably wider distribution in early Holocene and Pleistocene than currently. Fossil seeds were found in the postglacial sediments of the Moscow region, in lake Kosinskoe and Malomedvezhje, in Pleistocene sediments, on the Lower Kama, in singil layers of the Lower Volga and Akhtuba, along the Lower Don (Dorofeev, 1956), near Novokhopersk (Nikitin \& Dorofeev, 1953). Gorlova found fossil seeds of the plant in the Riss-Wurm (Mikulinsk) interglacial deposits on the left bank of the river Sarah in the neighbourhood of the village Levina Gora in the Yaroslavl region. As reported by Backman (1951), 31 postglacial records of this plant were known from the western part of Finland beyond its present range, and one location in interglacial sediments in north-western Germany in the region of the Lower Rhine and Wallenberg.

Currently Najas tenuissima is known from Finland, Latvia, Russia, northern and eastern Kazakhstan, Japan (Fig. 2; Appendix 1).

According to previously published data (Gorlova, 1960; Kolesnikova, 1965; Tzvelev, 1976), Najas tenuissima has a retrogressive disjunctive range.

We have attempted to generalise all the available information on the species distribution in the XIXXXI centuries. The species was first described from the territory of Finland and it was considered endemic. In 1852 Nylander and Chydenius found Najas tenuissima in lake Ruuanvesi in Southern Savonia (Samsel, 1939).
Later, several more locations were found. In 1857 and 1861 Saelan found Najas tenuissima in the river near Borgo city. Later, a location of this species was noted in lake Vesijärvi, in the gulf near Lehmoniemi in Southern Tavastia (17.08.1864, leg. J.P. Norrlin). In 1874 Saelan (29.07.1874) found Najas tenuissima near the Vyborg city in the sea bay (Samsel, 1939, reffering to Lindberg, 1900). Until 1906 Najas tenuissima was registered in 10 waterbodies of Finland in Rantasalmi, Borgo, Hollola and Vyborg (Backman, 1951; Gorlova, 1960). At present, special attention is paid to the study of the genus Najas in Finland since the species of this genus are endangered in the region. Ecology and biology of the species are well studied; coenotical relations are revealed (Uotila \& Tzvelev, 1998; Issakainen et al., 2011). During 1852-2010 Najas tenuissima was found in 31 waterbodies. The major number of locations in Finland was found in 2005 (Lampinen \& Lahti, 2016).

The species was found relatively recently (early 2000s) in Latvia. Uvis Suško found Najas tenuissima in two glacial lakes within the region: 1) Kräslava district, lake Ardavs, at the northern side of Hill Sauleskalns, August 6, 2006 (Suško, 2008). 2) lake Sivers, Ārdavs (Suško, 2015).

Before the XX century Najas tenuissima was considered as an endemic in Finland. But in 1895 Borodin first found this species in Russia - in lake Bologoe of the Valday county in Novgorod province (currently Tver region). Since 1897 Najas tenuissima is known from lake Piros, located $13 \mathrm{~km}$ north of lake Bologoe (Backman, 1951; Gorlova, 1960).

Single locations of the species are known in the north-west of Russia, in Central Russia, in the Southern Urals, in Eastern Siberia, in the Far East. The species is known from the Russian Far East - in the Amur region and south of Primorsky Krai.

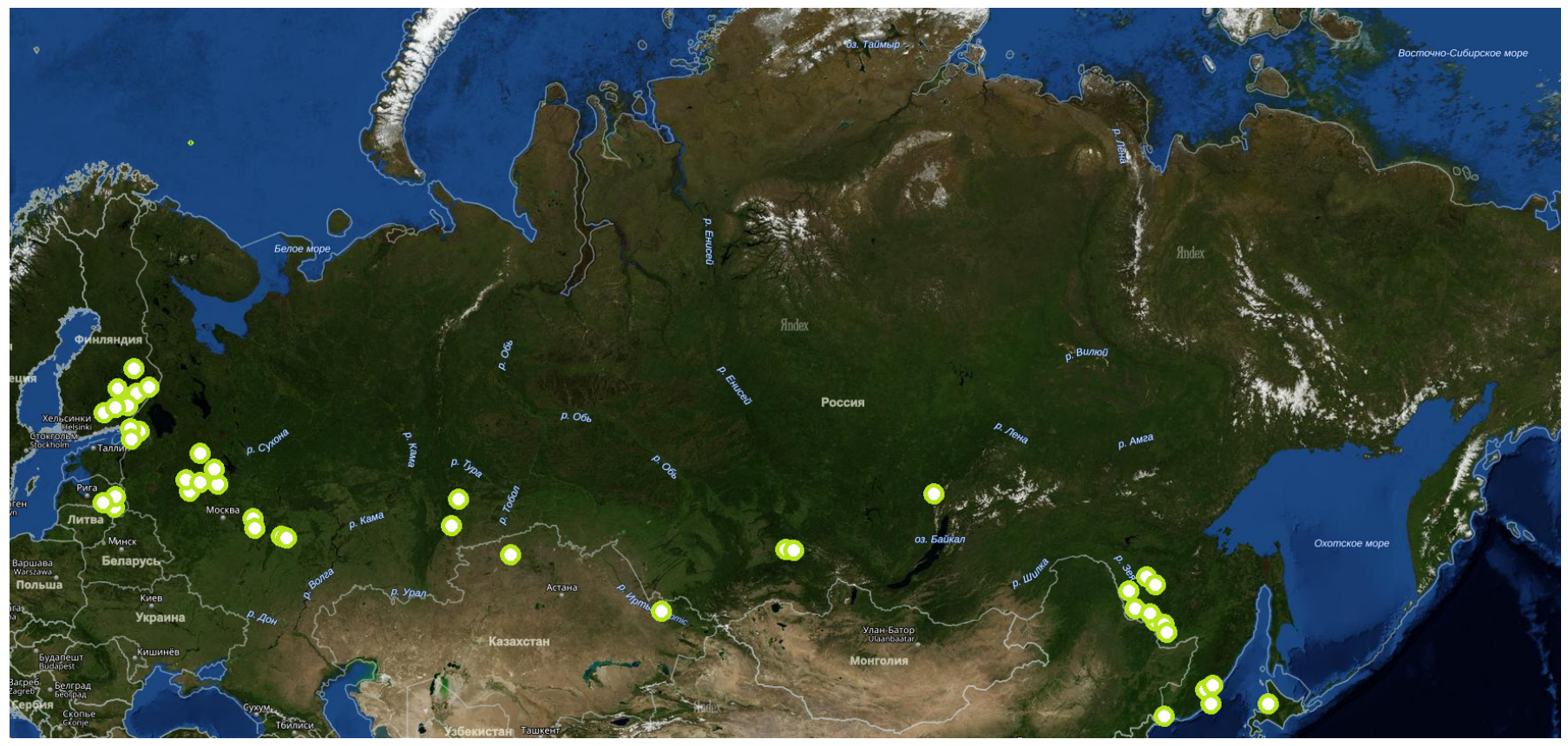

Fig. 2. Map of the current distribution of Najas tenuissima. 
Several locations are known in European Russia - in the north-western regions and in Central Russia.

Leningrad region. The coast of the Finnish Gulf in Vyborg district and in the neighbourhood of Saint Petersburg (near settlements Lakhta, Lisiy Nos, Razliv) (LE; Tzvelev, 1976, 2000a,b, 2004). In 1970s the species was known in Saint Petersburg from several areas at the northern coast of Neva Bay from Lakhta to Sestroretsk; by 2000s it was found in the neighbourhood of Lisiy Nos, in a small population (Tzvelev, 2004). There are two findings after 2000s. 1) Kingiseppsky district, partial reserve Kotelsky, $59^{\circ} 39^{\prime} 09^{\prime \prime} \mathrm{N}, 28^{\circ} 38^{\prime} 47^{\prime \prime} \mathrm{E}$, south-eastern shore of lake Glubokoe, at a depth of about $50 \mathrm{~cm}, 26.08 .2005$, leg. G.Yu. Konechnaya (LE); 2) Kotlin Island, Kronstadt, marshes in the northern part of the coast to the west of the dam, on silty-sandy shallow water at a depth of 20-45 cm in distance of 15-30 cm away of the island shore. It forms continuous cover under water, abundantly, 19.08.2006, leg. E.A. Glazkova (LE).

Novgorod region. Since 1960 Caulinia tenuissi$m a$ is known in lake Pestovo in Demyansky district (Krupkina et al. 2009), but since 1897 it known in lake Piros (boundary of Novgorod region and Tver region), located $13 \mathrm{~km}$ north of lake Bologoe in Tver region (Backman, 1950, Gorlova, 1960).

Tver region. In 1895 Borodin found Caulinia tenuissima in lake Bologoe in Valday county of Novgorod province (currently - Bologovsky district) (Tzvelev, 2000). In the XX century Najas tenuissima was found in lake Kolomenskoe in the Vyshnevolotsky district, in lake Ostrovno (07.08.1974, leg. L. Lisitsyna, IBIW) and Borovno (29.07.1975, leg. L. Lisitsyna, LE, IBIW). A revision of material from the locations in this region is needed (Red Data Book of Tver region, 2002).

Ryazan region. Klepikovsky district: 1) the backwater Prudkovskaya of lake Velikoe, 16.08.1936, leg. N.V. Samsel (MW; Samsel, 1939); 2) eastern shore of lake Velikoe, 15.08.1940, leg. N.V. Samsel (MW); 3) lake Velikoe, near the village Barskoe (observations of Shcherbakov, 1984); 4) in September 1984 Najas tenuissima was found in a large amount in shallow waters on the southern shore of lake Velikoe near the former village Gostyukhino (observations of Shcherbakov and his colleagues); 5); lake Beloe near the village Batykovo, significantly less than in lake Velikoe (observations of Shcherbakov, 1984: herbarium specimens were lost). As a result of special investigations in the early 2000 s the species was not found in lake Beloe, and only later (in 2007) a few individuals of Najas tenuissima were found in this lake: $8 \mathrm{~km}$ north of the Spas-Klepiki city, lake Beloe near the village Batykovo, rare nonnumerous groups in shallow waters, 12.08.2007, leg. A.V. Shcherbakov (MW). The species was cited in literature for lake Monastyrskoe near the village Solotcha in the Ryazan region (Tikhomirov, 1975); but it was established that this indication was based on an incorrect determination of a specimen of $\mathrm{Na}$ jas minor All. Later there were no new records of Najas tenuissima in the lakes of Central Meshchera for many years. In this regard Tikhomirov (1986) in «Determinant of plants of the Meshchera» suggested that Najas tenuissima was supplanted here by the grass species Zizania aquatica L. (Shcherbakov \& Kazakova, 2011).

Republic of Mordovia. In 2014 the species was found completely unexpectedly in the Temnikov district, in the ponds Bolshoy Filippovsky and Maly Filippovsky, $6 \mathrm{~km}$ southeast of the town Sarov: 15.08.2014, leg. E. Vargot, E. Yakunina (GMU, HMNR; Silaeva et al., 2014; Khapugin et al., 2016). Shoots of Najas tenuissima have been observed at a depth of 40-60 $\mathrm{cm}$ on the sandy ground near the embankments and on the eastern shallows of ponds. Plant thickets were found among sparse thickets of Potamogeton natans L., Elodea canadensis Michx. and Eleocharis acicularis (L.) Roem. \& Schult. More than 250 abundantly fruit-bearing plants were noted within the revealed populations. During the subsequent years the state of these populations has not been verified, because these ponds are located within the closed administrative-territorial formation Sarov, where there is strict access control.

The first location of Najas tenuissima in the Urals was found in the late XIX century: Perm province (currently - Sverdlovsk region), Ekaterinburgsky county, town of Verkhnyaya Pyshma, lake Isetskoe, in the water, June 1890, leg. O.E. Kler (SVER), determined by Andrey V. Shcherbakov. However, the species has not been found here since then.

The first record in Chelyabinsk region was registered in 2007. From 2007 to 2010 Najas tenuissima was regularly found in the northern part of lake Bolshoe Miassovo, where it grows at a depth of 0.5$1.0 \mathrm{~m}$ on the sandy or silty-sandy ground. The plants grow in sparse thickets together with Potamogeton perfoliatus L., P. pusillus L., Elodea canadensis, Callitriche hermaphroditica L. (Vejsberg, 2011).

Krasnoyarsky Krai. Kuraginsky district: 1) Mozharskie lakes, lake Spasskoe, 24.07.1969, leg. A.V. Kuminov, I.M. Krasnoborov (NS) (Volobaev, 1991); 2) lake Tiberkul (KRSU; Stepanov, 2011). Earlier Najas tenuissima was cited for Western Siberia, along the valley of the river Irtysh (Tzvelev, 1987). This record should be attributed to the territory of Eastern Kazakhstan (Volobaev, 1991).

Irkutsk region. Chepinoga et al. (2013) published a record of Najas tenuissima: Kazachinsko-Lensky district, foothills of Baikal ridge, the lower reaches 
of the Ozernaya river, lake Blizhnee, southern coastal zone; in lake, at a depth of $0.5 \mathrm{~m}$, absolute height $423 \mathrm{~m}, 56^{\circ} 13^{\prime} 504^{\prime \prime} \mathrm{N}, 108^{\circ} 01^{\prime} 613^{\prime \prime} \mathrm{E}, 09.08 .2012$, leg. V.V. Chepinoga, №29436, 29437. Chepinoga with co-authors (2013) wrote that, according to R.E. Romanov and A.V. Grebenyuk (Novosibirsk), the plants they had collected were not entirely typical for Najas tenuissima, and they are similar to the even rarer Far Eastern species $N$. japonica Nakai, according to some diagnostic features. Taxonomic revision of the genus in North Asia is needed.

Amur region. Najas tenuissima is observed in floodplains of the rivers Amur, Zeya, Bureya, Selemdzha (Bolotova \& Kozyr, 2008; Bolotova, 2009). Several locations are known in the region: Selemdzhinsky district: 1) N 52 ${ }^{\circ} 19^{\prime} 42.5^{\prime \prime}$, E 129 $54^{\prime} 22^{\prime \prime}$, neighbourhood of the settlement Norsk, backwater of the Aldikon river, 24.07.2006, leg. Ya.V. Bolotova, I.V. Kozyr; 2) N 52 $20^{\prime} 04.4^{\prime \prime}$, E $129^{\circ} 54^{\prime} 45.2^{\prime \prime}$, neighbourhood of the settlement Norsk, lake Kreshchenovskoe, 24.07.2006, leg. Ya.V. Bolotova, I.V. Kozyr; 3) Blagoveshchensky district, lakes near the railway station Belogorje, 27.06.2007, leg. Ya.V. Bolotova, M.G. Ivanchikova; Arkharinsky district: 4) neighbourhood of the village Kasatkino, lake Chekhovka, 06.07.2007, leg. Ya.V. Bolotova, G.F. Darman, V.M., Starchenko; 5) five km north-northeast of the village Novopokrovka, lake Peschanoe, 07.07.2007, leg. Ya.V. Bolotova, G.F. Darman, V.M. Starchenko; 6) lake Fedorovskoe - between village KazanovkaSvobodnoe, 09.07.2007, leg. Ya.V. Bolotova, G.F. Darman, V.M. Starchenko; Bureysky district: 7) neighbourhood of the settlement Progress, flowage lake through the Kivda river, near the bridge, 11.07.2007, leg. Ya.V. Bolotova, V.M. Starchenko, G.F. Darman; 8) water body to the right of the road Blagoveshchensk - Raychikhinsk, 11.07.2007, leg. Ya.V. Bolotova, G.F. Darman, V.M. Starchenko; 9) water body to the left of the road Blagoveshchensk - Raychikhinsk, 11.07.2007, leg. Ya.V. Bolotova, G.F. Darman, V.M. Starchenko; 10) Svobodnensky district, neighbourhood of the Svobodny city, 27.07.2008, leg. Ya.V. Bolotova, I.V. Shulga. Probably the species could also be found in the Norsky Reserve. Since the species in the Russian Far East grows in the floodplain of the Amur river, we have great reason to expect findings of Najas tenuissima in similar waterbodies on the right bank of this river in China.

Primorsky Krai. Khasansky district, small waterbody near the coast, between the villages Zarubino and Andreevka (Tzvelev, 1987). Najas tenuissima has been found recently in the Middle SikhoteAlin: Dalnegorsky district, lakes Yaponskoe, Golubichnoe and small unnamed lake in the valley of the
Serebryanka river (Nesterova, 2008; Red Data Book of the Primorsky Krai, 2008; Baykov, 2012).

For Kazakhstan Najas tenuissima is given in the monograph «Flora and vegetation of waterbodies in Northern Kazakhstan» (Sviridenko, 2000): rarely, in rivers and water reservoirs, on muddy grounds at a depth of up to $0.5 \mathrm{~m}$ (water reservoir Sergeevskoe, the upper part, sparsely, 8.07.1984). According to Kolesnikova (1965), this species is given for Eastern Kazakhstan: Markakolsky district, shore of oxbow lake of the Irtysh river in Buran, 9.08.1930, №1018, N. Goncharov, leg. A. Borisova (in admixture with C. minor) (LE).

Najas yezoensis Miyabe is listed for Japan (Hokkaido island) (Ōi et al., 1965; Tzvelev, 1987). Currently this plant name is regarded as a heterotypic synonym of Najas tenuissima (Govaerts, 2016: referring to Kharkevich, 1987 with the name Caulina tenuissima).

Thus, all the locations of Najas tenuissima could be divided into two groups: locations found before 1990 s, and those found after 2000 s until now. So, between 1990 and 2000 there are no findings. The species is known currently from lakes in Finland, lake Ostrovno and Borovno in the Tver region, lake Beloe (Belozerie) in the Ryazan region. In the XXI century there are new findings in Latvia, Filippovskie ponds in CATF Sarov (Republic of Mordovia), lake Bolshoe Miassovo in Chelyabinsk region, lake Blizhnee in Irkutsk region, in floodplain waterbodies of Amur region, lakes in the Serebryanka river valley in Primorsky Krai. Other locations require an inventory. It is necessary to provide an annual monitoring of waterbodies - habitats of Najas tenuissima, because of the nature of the life cycle of aquatic annuals, this species (under different weather conditions in different years) can either grow in mass or remain in the seed phase in the bottom soil of the waterbody; these seeds can maintain their germinability up to 50 years or more (authors' observations).

\section{On the possible causes of rarity of Najas tenuissima}

On the basis of generalisation of palaeobotanical and modern material on the distribution of Najas tenuissima, Gorlova (1960) in her paper «About current and past distribution of Najas tenuissima A. Br.» noted that climate changes and changes in the water composition are not the reasons for the reducing of its former range. She suggested that the competition with other aquatic plants is one of the causes of the species extinction. Shcherbakov \& Kazakova showed, in the Red Data Book of Ryazan region (2011), the impact of the overgrowing of waterbodies on Najas tenuissima populations: «backwater Prudkovskaya of lake Velikoe is overgrown strongly; and the whole lake 
became much more eutrophic; therefore the existence of Najas tenuissima here is extremely limited».

Najas tenuissima occurs in aqueoglacial lakes with fresh water. The species was also known in the desalinated water of the Finnish Gulf in the Leningrad region. Many of these habitats suffered of direct or indirect anthropogenic influence (civil engineering work, change of the hydrological regime of lakes, water logging and overgrowing shores). The hydrological regime of habitats began to change, lakes became shallower. This in turn contributed to the thicket development of aquatic and coastal-water species (which are strong competitors) in shallow waters. Najas tenuissima is common in Southern Finland and the Amur region; the species grows in a significant number of populations and is able to form stable populations. It grows in floodplain waterbodies in the Amur region. Najas tenuissima grows in stagnant shallow $(0.3-0.5 \mathrm{~m})$, well-warmed water bodies with clear water and slightly silted bottom. The plant forms vast underwater meadows-thickets in each of these habitats. It abundantly blooms and fructifies, including the population in the neighbourhood of the settlement Norsk (Selemdzhinsky district) (Bolotova \& Kozyr, 2008).

Single recent records have been made among others in ponds, a tectonic lake, backwater of a river. Thus, this species prefers continental lakes, but it grows in various waterbodies and water courses of other types. In general, Najas tenuissima prefers fresh, well-warmed waters, sandy or slightly muddy grounds and a lack of water flow; besides it grows in places where there is no competition with other plant species.

Summarising data of literature, herbaria and personal observations, we conclude that reduction of the former range of the species in the past geological times is most likely associated with a variety of factors. In particular it could be due to changes in the thermal regime of waterbodies as a result of climate changes. This caused the overgrowing of waterbodies and the ousting of this species by other plants. Direct extinction of species populations took place at complete overgrowing of waterbodies. Under the current conditions, eutrophication of waterbodies and irrigation-drainage works in adjacent areas are two other factors unfavourable for this species.

Siltation is the reason of a mass overgrowth with thickets of widely spread aquatic and coastal macrophytes, gradual overgrowing of shallow waters which are typical habitats for annual hydrophytes. Under these conditions, aquatic annuals cannot compete with perennials and they gradually reduce. Different plant communities and vascular plants involved in their formation can dominate in aquatic ecosystems at different times. This is often caused by the combination (which is sometimes unknown) of natural and anthropogenic factors affecting alone or together. Species of the genus Najas and other aquatic annuals manifest themselves and develop only in the most favourable years with a warm spring and summer, optimal precipitation, snow melting, water activity during flood. Temporary shallowing of riverbeds and basins of waterbodies is an important positive factor for the growth of annual hydrophytes. All this causes that Najas populations do not appear annually (Shcherbakov \& Kazakova, 2011; Vargot, 2015). Under such conditions it is difficult to judge about species disappearance, because the species may be presented in the waterbody in latent state in the form of fruits during more than 50 years. Therefore, often the conclusion about the disappearance of populations of aquatic annuals in a certain waterbody cannot be taken for $100 \%$.

By analysing the number and dates of records of Najas tenuissima over the last 160 years from Finland, Latvia, European Russia, Japan, it becomes clear that the major number of records was registered during 1857-1936. Then the researchers noted the absence or presence of this species in already known locations; the problem of recent reducing of the species range has been discussed. After a long interval, data on single records of the species in European Russia, in the Urals, in Siberia and the Far East began to emerge in 2006-2014. Two records of Najas tenuissima (in the floodplain of the river Irtysh near Buran in Kazakhstan and on Mozharskie lake) have not been taken into account for a long time in the description of the species range. It is difficult to judge on the appearance of new populations in Chelyabinsk region, Irkutsk region, Amur region, Republic of Mordovia. It is not excluded that the species aims to occupy new territories, like, for example, Najas major All. and N. minor. But in that case the main limiting factor for Najas tenuissima is the small abundance of suitable lakes (in particular, tectonical and aqueoglacial lakes with clear water and suitable ground or waterbodies with a similar hydrological regime), where competition with other species is minimal.

In general, if we talk about Najas tenuissima as an annual plant, it is impossible to say exactly what its populations forced out by thickets of other plants or if it even disappears. The dynamics of the hydrological regime of the water body is an important factor for this annual plant. Most likely, the factors affecting the dynamics of water cut and thermal regime of habitats play a crucial role in the development of aquatic macrophytes communities, including Najas tenuissima populations. 


\section{Conclusions}

Najas tenuissima is one of the rarest aquatic relict plants with a disjunctive range. Therefore the nature of the current distribution of the species is of great scientific interest. There are more than 60 locations of this species found from the beginning of its description in 1864; of them more than 30 locations are in Finland. Taking into account the past and present distribution of the species, Najas tenuissima undoubtedly deserves protection. Its inclusion in the Red Data Books of the USSR (1978, 1984), RSFSR (1988), Eastern Fennoscandia (1998), Russian Federation (Bardunov \& Novikov, 2008), and in many regional Red Data Books has contributed to its conservation. The most effective way of conservation of Najas tenuissima (as well as other rare aquatic plants) is its conservation in Protected Areas (Vargot, 2010; Bolotova, 2011). The lakes of Bologoe, Piros, Velikoe, Beloe and Filippovskie ponds are Protected Areas (as natural monuments) of regional importance. The species is protected in the Ilminsky Reserve in the Chelyabinsk region; it is protected within the boundaries of the natural monument «Lake Tiberkul» in the Krasnoyarsky Krai. The main reason for its extinction may be the habitat destruction, that manifests itself in the changing of the hydrological and hydrochemical regimes of waterbodies, and, as a consequence, in its overgrowing.

As mentioned above, Najas tenuissima cannot manifest itself in waterbodies every year because of the nature of its biology. In this regard, it is necessary to maintain annual monitoring of the species' populations. However, this is quite difficult to carry out outside Protected Areas. But, within nature reserves, national parks and natural monuments, it is necessary to conduct annual studies as well as population-based studies throughout the vegetative period, measurements of physicochemical water parameters, monitoring of the water level dynamics, processes of sludge buildup, overgrowing of waterbodies with a subsequent publication of these data.

\section{Acknowledgements}

We thank to Ms. Marja Koistinen (Helsinki) for useful discussions and information on some Finnish localities of species. Authors are grateful to Jacob Koopman and Anatoliy A. Khapugin for valuable comments and advice which has improved the quality of our paper. This work was supported by the Ministry of Education and Science of Russia (project № 6.783.2014K) and Government order for the Lomonosov Moscow State University (project No.AAAA-A16-116021660045-2.

\section{References}

APG II. 2003. An update of the Angiosperm Phylogeny Group classification for the orders and families of flowering plants:
APG II. Botanical Journal of the Linnean Society 141: 399-436. doi:10.1046/j.1095-8339.2003.t01-1-00158.x

APG III. 2009. An update of the Angiosperm Phylogeny Group classification for the orders and families of flowering plants: APG III. Botanical Journal of the Linnean Society 161: 105-121

Backman A.L. 1951. Najas tenuissima (A.Br.) Magnus einst und jetst. Societas scientianum Fennica commentationes Biologicae 10 (19): 1-36. [In German]

Bardunov L.V., Novikov V.S. (eds.). 2008. Red Data Book of Russian Federation (plants and fungi). Moscow: KMK Scientific Press Ltd. 855 p. [In Russian]

Baykov K.S. (ed.). 2012. Synopsis of Asiatic Russia flora: vascular plants. Novosibirsk: Publisher of Siberian Branch of the Russian Academy of Sciences. 640 p. [In Russian]

Bolotova Ya.V. 2009. Thinnest Naiad - Caulinia tenuissima (A. Br. ex Magnus) Tzvelev. In: Red Data Book of the Amur region: rare and endangered species of animals, plants and mushrooms. Blagoveshchensk: Publisher of the Blagoveshchensk State Pedagogical University. P. 255-256. [In Russian].

Bolotova Ya.V. 2011. The Amur Region water plants and the issues of their protection. The Bulletin of KrasGAU 11: 145-146 [In Russian].

Bolotova Ya.V., Kozyr I.V. 2008. Caulinia tenuissima (Najadaceae), a new species for the flora of Amur Region. Botanicheskiy Zhurnal 93 (9): 145-146 [In Russian].

Chepinoga V.V., Dementjeva M.K., Lishtva A.V. 2013. Floristic findings in the upper part of the Lena River basin (Irkutsk Region). Bulletin of Irkutsk State University 6 (1): 102-109. [In Russian]

Dorofeev P.I. 1956. Pleistocene floras of the Lower Volga and Akhtuba. Botanicheskiy Zhurnal 41 (6): 810-829. [In Russian]

Govaerts R. 2016. World Checklist of Hydrocharitaceae. Facilitated by the Royal Botanic Gardens, Kew. Published on the Internet. Available at: http://apps.kew. org/wcsp/namedetail.do;jsessionid $=601110 \mathrm{~B} 93 \mathrm{~F} 80$ 9452CEFC3F9DA4EBE159?name $\mathrm{id}=309067$. Accessed on 07.10 .2016

Gorlova R.N. 1960. On present and past distribution of Najas tenuissima A. Br. Bulletin of Moscow Society of Naturalists Biological series 65 (6): 60-64. [In Russian]

Issakainen J., Kemppainen E., Mäkelä K., Hakalisto S., Koistinen M. 2011. Hentonäkinruoho (Najas tenuissima) ja notkeanäkinruoho (Najas flexilis) Suomen uhanalaisia lajeja. Helsinki: Suomen ympäristökeskus. 223 p. [In Finnish]

IUCN. 2016. The IUCN Red List of Threatened Species. Version 2016-2. Available at http://www.iucnredlist.org. [Accessed on 03 September 2016].

Kazakova M.V. 2004. Flora of the Ryazan Region. Ryazan: Russkoe slovo. 388 p. [In Russian]

Khapugin A.A., Silaeva T.B., Vargot E.V., Chugunov G.G. 2016. IUCN guidelines using for assessment of plants from the Red Book of Russian Federation at regional level: a case study for the Republic of Mordovia (Russia). Hacquetia. doi: 10.1515/hacq-2016-0012.

Kharkevich S.S. (ed.). 1987. Plantae Vasculares Orientalis Extremi Sovietici. Vol. 2. Leningrad: Nauka. P. 1-448. [In Russian]

Kolesnikova T.D. 1965. Recent and past distribution of the species of the genus Najas L. in the USSR and their significance for the paleogeography of the Qua- 
ternary Period. Botanicheskiy Zhurnal 50 (2): 182190. [In Russian]

Krupkina L.I., Konechnaya, G.Yu., Yurova E.A. 2009. Localities of rare species of vascular plants in Novgorod Region. In: E.A. Yurova, L.I. Krupkina, G.Yu. Konechnaya (eds.): Checklist of the flora of Novgorod Region. Novgorod: LEMA Publishers. P. 120-167. [In Russian]

Lampinen R., Lahti T. 2016. Kasviatlas 2015. Helsinki: Helsingin Yliopisto, Luonnontieteellinen keskusmuseo. Available at: http://www.luomus.fi/kasviatlas (Assessed on 30.09.2016). [In Finnish]

Lindberg H. 1900. De I Finland förekommande arterna af slăgtet Najas. Meddelanden af Societatis pro Fauna et Flora Fennica 25: 48. [In Finnish]

Lisitsyna L.I., Papchenkov V.G., Artemenko V.I. 2009. Flora of the Volga basin waterbodies. Determinant of vascular plants. Moscow: KMK Scientific Press Ltd. 219 p. [In Russian]

Magnus P.W. 1870. Beitrage zur Kenntniss der Gattung Najas. Berlin: Druck und Verlag von Georg Reimer. $96 \mathrm{~S}$. [In German]

Nikitin P.A., Dorofeev P.I. 1953. Quaternary flora of neighborhoods of Novokhopersk city. Bulletin of the Commission for Quaternary Research 17: 22-39. [In Russian]

Ōi J., Meyer F.G., Walker E.H. 1965. Flora of Japan (in English): a combined, much revised, and extended translation by the author of his Flora of Japan (1953) and Flora of Japan, Pteridophyta (1957). Washington: Smithsonian Institution. $1114 \mathrm{p}$.

Red Data Book of RSFSR. Plants. Moscow: Publisher «Rosagropromizdat», 1988. 591 p. [In Russian]

Red Data Book of the Primorsky Krai: Rare and endangered species of plants and fungi. Vladivistok: ABK «Apelsin», 2008. 688 p. [In Russian]

Red Data Book of the Tver region. Tver: «Veche Tveri»; «Publisher ANTEK», 2002. 256 p. [In Russian]

Red Data Book of USSR. Rare and endangered species of animals and plants. Moscow: Lesnaya promyshlennost, 1978. 406 p. [In Russian]

Red Data Book of USSR. Rare and endangered species of animals and plants. Moscow: Lesnaya promyshlennost. Moscow: Lesnaya promyshlennost, 1984. 480 p. [In Russian]

Resolution of the Government of the Republic of Mordovia № 559 from October 1, 2015. 2015. «On Amending Resolution of the Government of the Republic of Mordovia from February 25, 2003 № 61: “About the Red Data Book of rare and endangered species of plants, fungi and animals of the Republic of Mordovia"». [In Russian]

Samsel N.V. 1939. About distribution of Najas tenuissima A.Br. Bulletin of Moscow Society of Naturalists Biological series 48 (5-6): 108-111. [In Russian]

Shcherbakov A.V., Kazakova M.V. 2011. Thinnest Naiad - Najas tenuissima A. Br. ex Magnus. In: Red Data Book of the Ryazan region. Ryazan. P. 361-362. [In Russian]

Silaeva T.B., Vargot E.V., Khapugin A.A., Urbanavichyus G.P., Urbanavichene I.N., Ageeva A.M., Ivoylov A.V., Chugunov G.G., Kiryukhin I.V. 2014. Rare plants and fungi: materials for maintenance of the Red Book of the Republic of Mordovia for 2014. Saransk: Publisher of the Mordovia State University. 92 p. [In Russian]

Stepanov N.V. 2012. Thinnest Naiad - Caulinia tenuissima (A. Br. ex Magnus) Tzvelev. In: N.V. Stepanov (ed.): Red Data Book of the Krasnoyarsky Krai: rare and endangered spe- cies of plants and fungi. Krasnoyarsk: Publisher of the Siberian Pedagogical University. P. 208. [In Russian]

Suško U. 2008. Najas tenuissima - a new macrophyte species in flora of the Baltic Countries. Botanica Lithuanica 14: 65-67.

Suško U. 2015. Nature values of lake Sivers and lake Ārdavs and their surroundings in contecst conservation of Najas flexilis and $N$. tenuissima habitats. In: $8^{\text {th }}$ Intrnational Conference on Biodiversity Research. Books of abstracts. Daugavpils: Daugavpils University Academic Press «Saule». P. 149.

Sviridenko B.F. 2000. Flora and vegetation of waterbodies in Northern Kazakhstan. Omsk: Publisher of the Omsk State Pedagogical University. 196 p. [In Russian]

Tikhomirov V.N. (ed.). 1975. Synopsis of the flora of Ryazan Meshchera. Moscow: Lesnaya promyshlennost. 328 p. [In Russian]

Tikhomirov V.N. (ed.). 1986. Determinant of plants of the Meshchera. Moscow: Publisher of the Moscow State University. 240 p. [In Russian]

Tzvelev N.N. 1976. Note about genus Najas L. in USSR. Novosti sistematiki vysšich rastenij 13: 16-20. [In Russian]

Tzvelev N.N. 1987. Family Najadaceae Juss. In: Vascular plants of the Far East. Vol. 2. Leningrad: Nauka. P. 342345. [In Russian]

Tzvelev N.N. 2000a. Manual of the vascular plants of NorthWest Russia (Leningrad region, Pskov region and Novgorod region). Saint Petersburg: St.-Petersburg State Chemical-Pharmaceutical Press. 781 p. [In Russian]

Tzvelev N.N. 2000b. Thinnest Naiad - Caulinia tenuissima (Najas tenuissima A. Br. ex Magnus). In: Red Data Book of Nature of Leningrad Region. Saint-Petersburg: Publisher «Mir i Semja». Pp. 206-207. [In Russian]

Tzvelev N.N. 2004. Thinnest Naiad - Caulinia tenuissima (Najas tenuissima A. Br. ex Magnus). In: Red Data Book of Nature of Saint-Petersburg. Saint-Petersburg: Autonomous nonprofit scientific-educational Organization «Professional». P. 307. [In Russian]

Tzvelev N.N. 2008. Thinnest Naiad - Caulinia tenuissima (A. Br. ex Magnus) Tzvelev. In: Red Data Book of the Russian Federation (plants and fungi). Moscow: KMK Scientific Press Ltd. P. 347-348. [In Russian]

Uotila P. 2009. Najadaceae. In: Euro+Med Plantbase - the information resource for Euro-Mediterranean plant diversity. Available at http://ww2.bgbm.org/EuroPlusMed/ (Accessed on 28.09.2016)

Uotila P., Tzvelev N.N. 1998. Najas tenuissima (Najadaceae). In: H. Kotiranta, P. Uotila, S. Sulkava, S.-L. Peltonen (ed.): Red Data Book of East Fennoscandia. Helsinki: Ministry of the Environment, Finnish Environment Institute \& Botanical Museum, Finnish Museum of Natural History. P. 92-93. [In Finnish]

Vargot E.V. 2010. Conservation problems of aquatic plants in the Middle Sura basin. Mordovia University Bulletin 1: 82-91. [In Russian]

Vargot E.V. 2015. Long-term dynamics of populations of rare aquatic plants in the National Park «Smolny». Proceedings of the National Park «Smolny» 2: 3-10. [In Russian]

Veisberg E.I. 2011. Species of family Najadaceae in Southern Ural. Botanicheskiy Zhurnal 96 (11): 1470-1473. [In Russian]

Volobaev A.A. 1991. New and rare aquatic vascular plant species for the flora of Siberia. Botanicheskiy Zhurnal 76 (4): 616-618. [In Russian] 
Appendix 1. Locations of Najas tenuissima currently known

\begin{tabular}{|c|c|}
\hline Region & Locations \\
\hline Finland & $\begin{array}{l}\text { lake Ruuanvesi in Southern Savonia, in the river near Borgo city, lake Vesijärvi, in the gulf near } \\
\text { Lehmoniemi in Southern Tavastia, near Vyborg city in the gulf; and other lakes }\end{array}$ \\
\hline Latvia & lake Ardavs, lake Sivers \\
\hline Kazakhstan & water reservoir Sergeevskoe, oxbow lake of the Irtysh river \\
\hline Japan & island Hokkajdo \\
\hline \multicolumn{2}{|r|}{ Russian Federation } \\
\hline Novgorod region & lake Piros, lake Pestovo in the Demyansky district \\
\hline Leningrad region & $\begin{array}{l}\text { Marshes along north coast of island Kotlin, lake Glubokoe in the Kotelskiy Reserve, Finnish Gulf } \\
\text { in Vyborg district and in the neighbourhood of Saint Petersburg (near settlements Lakhta, Lisiy } \\
\text { Nos, Razliv) }\end{array}$ \\
\hline Tver region & lake Bologoe, lake Kolomenskoe, lake Ostrovno, lake Borovno \\
\hline Ryazan region & $\begin{array}{l}\text { backwater Prudkovskaya in lake Velikoe, near the village Barskoe; lake Beloe near the village } \\
\text { Batykovo }\end{array}$ \\
\hline Republic of Mordovia & in the ponds Bolshoy Filippovsky and Maly Filippovsky \\
\hline Sverdlovsk region & lake Isetskoe \\
\hline Chelyabinsk region & northern part of lake Bolshoe Miassovo \\
\hline Krasnoyarsky Krai & Mozharskie lakes, lake Spasskoe, lake Tiberkul \\
\hline Irkutsk region & lower reaches of the Ozernaya river, lake Blizhnee \\
\hline Amur region & lakes in floodplains of the rivers Amur, Zeya, Bureya, Selemdzha \\
\hline Primorsky Krai & small waterbody near the coast between the villages Zarubino and Andreevka \\
\hline
\end{tabular}

\title{
СОВРЕМЕННОЕ РАСПРОСТРАНЕНИЕ И СОХРАНЕНИЕ NAJAS TENUISSIMA (HYDROCHARITACEAE)
}

\author{
Е. В. Варгот ${ }^{1,2,3}$, А. В. Щербаков ${ }^{4}$, Я. В. Болотова ${ }^{5}$, П. Уотила ${ }^{6}$ \\ ${ }^{1}$ Мордовский государственный природный заповедник им. П.Г. Смидовича. Россия \\ ${ }^{2}$ Национальный исследовательский Мордовский государственный университет им. Н.П. Огарева, Россия \\ ${ }^{3}$ Наииональный парк «Смольный», Россия \\ e-mail:vargot@yandex.ru \\ ${ }^{4}$ Московский государственный университет им. М.В. Ломоносова, Россия \\ e-mail:shch_a_w@mail.ru \\ ${ }_{5}^{5}$ Амурский филиал ботанического сада-института ДВО РАН, Россия \\ e-mail:yabolotova@mail.ru \\ ${ }^{6}$ Университет Хельсинки, Финляндия \\ e-mail:perti.uotila@helsinki.fi
}

\begin{abstract}
Najas tenuissima (Hydrocharitaceae) - реликтовый исчезающий вид с дизъюнктивным ареалом в Восточной Европе, на Урале, в Сибири и Казахстане, на Дальнем Востоке, в Японии. Достоверно вид известен в Финляндии, Латвии, Ленинградской, Новгородской, Тверской, Рязанской областях, Республике Мордовия, Свердловской, Челябинской, Иркутской, Амурской областях, Красноярском и Приморском краях Российской Федерации, Северном и Восточном Казахстане, Японии. За 160 лет современной истории вида выявлено более 60 местонахождений Najas tenuissima. Более 30 из них приходится на водоемы Южной Финляндии. В статье обобщаются сведения о местонахождениях вида в выше указанных регионах, высказывается предположение о произрастании его в пойменных водоемах правобережья Амура в Китае. Приводятся рассуждения о причинах исчезновения Najas tenuissima. Как основной фактор, вызывающий сокращение численности вида в XX-XXI вв. обозначено антропогенное воздействие на водные экосистемы. Отмечено уменьшение числа популяций, выявленных в период с 1857 по 1936 гг. (в Ленинградской, Тверской, Новгородской и Рязанской областях России), появление новых популяций в период с 2006 по 2016 гг. (в Латвии, Амурской, Челябинской, Иркутской областях, Республике Мордовия, Приморском крае России). Высказывается предположение о возможном заселении видом новых пространств. Отмечается, что сохранение вида возможно только при условии организации территориальной охраны местообитаний Najas tenuissima.
\end{abstract}

Ключевые слова: Najas tenuissima, ареал, Красная книга, особо охраняемые природные территории, расселение вида, реликтовый вид. 